\title{
Caelestines A-D, Brominated Quinolinecarboxylic Acids from the Australian Ascidian Aplidium caelestis
}

\author{
Sheng Yin, ${ }^{\dagger}$ Glen M. Boyle, ${ }^{\ddagger}$ Anthony R. Carroll, ${ }^{\dagger}$ Michael Kotiw, ${ }^{\S}$ John Dearnaley, ${ }^{\S}$ \\ Ronald J. Quinn, ${ }^{\dagger}$ and Rohan A. Davis ${ }^{* \dagger}$
}

Eskitis Institute, Griffith University, Brisbane, QLD 4111, Australia

Queensland Institute for Medical Research, Herston, Queensland, Australia, 4006

Department of Biological and Physical Sciences, University of Southern Queensland, Toowoomba, QLD 4351, Australia

\footnotetext{
* To whom correspondence should be addressed. Tel: +61-7-3735-6043. Fax: +61-7-37356001; E-mail: r.davis@griffith.edu.au

${ }^{\dagger}$ Eskitis Institute

${ }^{\ddagger}$ Queensland Institute for Medical Research

${ }^{\S}$ University of Southern Queensland
} 
ABSTRACT: Four new brominated natural products, caelestines A-D (1-4), have been isolated from the Australian ascidian Aplidium caelestis. The structures of 1-4 were determined by analysis of their NMR and MS data. This is the first report of brominated quinolinecarboxylic acids from nature. Compound $\mathbf{1}$ has been previously synthesized but not spectroscopically characterized. Compounds $\mathbf{1 - 4}$ were tested against three mammalian cell lines (MCF-7, NFF, and MM96L) and a panel of microbial strains and only showed minor cytotoxicity. 
2-Quinolinecarboxylic acid derivatives are relatively uncommon in nature. To date, about 20 simple quinolinecarboxylic acids have been isolated from insects, ${ }^{1-4}$ bacteria, ${ }^{5-7}$ and plants. ${ }^{8-10}$ Xanthurenic acid, or 4,8-dihydroxy-2-quinolinecarboxylic acid, a metabolite of tryptophan, is present in the urine of vitamin $\mathrm{B}_{6}$-deficient rats. ${ }^{11}$ The 8-methoxy derivative of xanthurenic acid is a possible endogenous carcinogen. ${ }^{12}$ Only seven quinolinecarboxylic acid derivatives have been reported from marine organisms. These include 4,5,8trihydroxyquinolinecarboxylic acid from the Antarctic sponge Dendrilla membranosa, ${ }^{13}$ xanthurenic acid and its derivatives, tridemnic acids $\mathrm{A}$ and $\mathrm{B}$, that were isolated from the Canadian ascidian Trididemnum sp., ${ }^{14}$ distomadine B, which was isolated from the New Zealand ascidian Pseudodistoma aureum, ${ }^{15}$ and perspicamides A and B, that were purified from the Australian ascidian Botrylloides perspicuum. ${ }^{16}$ As part of our continuing efforts to discover new chemistry from Australian ascidians, ${ }^{16-19}$ we undertook a detailed chemical analysis of the previously uninvestigated ascidian, Aplidium caelestis. These studies resulted in the isolation of four new brominated natural products, caelestines A-D (1-4). The structures of 1-4 were determined by analysis of the NMR and MS data. Compound $\mathbf{1}$ has been previously synthesized but not spectroscopically characterized. This is the first report of brominated quinolinecarboxylic acids from nature. Caelestines A-D (1-4) were tested against three mammalian cell lines (MCF-7, NFF, and MM96L) and a panel of microbial strains and only showed minor cytotoxicity. In this paper we report the isolation, structure elucidation, as well as the bioactivity of compounds 1-4.

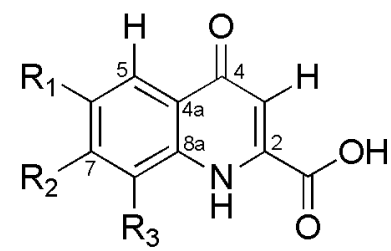

$1 \mathrm{R}_{1}=\mathrm{H} \quad \mathrm{R}_{2}=\mathrm{Br} \mathrm{R}_{3}=\mathrm{H}$

$2 \mathrm{R}_{1}=\mathrm{Br} \mathrm{R}_{2}=\mathrm{Br} \mathrm{R}_{3}=\mathrm{H}$

$3 \quad \mathrm{R}_{1}=\mathrm{Br} \quad \mathrm{R}_{2}=\mathrm{H} \quad \mathrm{R}_{3}=\mathrm{OMe}$

$4 \mathrm{R}_{1}=\mathrm{Br} \mathrm{R}_{2}=\mathrm{Br} \mathrm{R}_{3}=\mathrm{OMe}$ 
The freeze-dried and ground ascidian A. caelestis was exhaustively extracted with $n$ hexanes, $\mathrm{CHCl}_{3} / \mathrm{MeOH}(4: 1)$, and $\mathrm{MeOH}$. The $\mathrm{CHCl}_{3} / \mathrm{MeOH}$ extracts were all combined and chromatographed using reversed-phase $\mathrm{C}_{18}$ HPLC $\left(\mathrm{MeOH} / \mathrm{H}_{2} \mathrm{O} / 0.1 \%\right.$ TFA) to yield caelestines A-D (1-4).

Caelestine A (1) was isolated as a pale gum. The (+)-LRESIMS spectrum showed an isotopic cluster of $[\mathrm{M}+\mathrm{H}]^{+}$ions in the ratio of $1: 1$ at $\mathrm{m} / \mathrm{z} 268 / 270$, indicating the presence of one bromine atom. The $[\mathrm{M}+\mathrm{H}]^{+}$ion in the $(+)$-HRESIMS spectrum at $\mathrm{m} / \mathrm{z} 267.9597$ allowed the molecular formula $\mathrm{C}_{10} \mathrm{H}_{6} \mathrm{BrNO}_{3}$ to be assigned to $\mathbf{1}$. The ${ }^{1} \mathrm{H}$ NMR data (Table 1) of $\mathbf{1}$ showed signals for two exchangeable protons [ $\delta_{\mathrm{H}} 11.98$ (brs) and 11.14 (s)], a 1,2,4trisubstituted benzene ring [ $\delta_{\mathrm{H}} 7.98(\mathrm{~d}, J=8.6 \mathrm{~Hz}), 7.50(\mathrm{dd}, J=8.6,1.8 \mathrm{~Hz})$, and $8.17(\mathrm{~d}, J=$ $1.8 \mathrm{~Hz})]$, and an olefinic singlet $\left(\delta_{\mathrm{H}} 6.63\right)$. The ${ }^{13} \mathrm{C}$ NMR spectrum together with HSQC experiment revealed 10 carbon resonances which included two carbonyl signals $\left(\delta_{\mathrm{C}} 177.2\right.$ and 163.4), four $\mathrm{sp}^{2}$ methines ( $\delta_{\mathrm{C}} 110.5,127.0,127.0$, and 121.8$)$, and four quaternary $\mathrm{sp}^{2}$ carbons $\left(\delta_{\mathrm{C}} 139.5,126.0,141.1\right.$, and 124.5$)$. The aforementioned data was similar to that 4 -oxo1,4-dihydroquinoline-2-carboxylic acid ${ }^{10}$ except that one of the aromatic protons in 4-oxo1,4-dihydroquinoline-2-carboxylic acid was replaced with a bromine atom in $\mathbf{1}$. This was supported by the ABX substitution pattern of the benzene ring and the presence of the bromine atom in molecular formula of $\mathbf{1}$. Detailed analysis of the 2D NMR data (HSQC and HMBC) of $\mathbf{1}$ allowed the bromine atom to be positioned at C-7. In particular the intensity of the HMBC correlations assisted in the unambiguous assignment of the brominated benzenoid system (see Supporting Information). Strong ${ }^{3} J_{\mathrm{CH}}$ HMBC correlations from the aromatic proton at $\delta_{\mathrm{H}} 7.98$ to C-4 ( $\left.\delta_{\mathrm{C}} 177.2\right), \mathrm{C}-7\left(\delta_{\mathrm{C}} 126.0\right)$, and C-8a $\left(\delta_{\mathrm{C}} 141.1\right)$ placed this proton at C-5, while the proton at $\delta_{\mathrm{H}} 8.17$ was positioned at C-8 due to HMBC correlations between $\mathrm{H}$ 8 and C-4 $\left({ }^{4} J_{\mathrm{CH}}\right.$, weak correlation), C-6 $\left({ }^{3} J_{\mathrm{CH}}\right)$ and C-4a $\left({ }^{3} J_{\mathrm{CH}}\right)$ (Figure 1). The proton at $\delta_{\mathrm{H}}$ 7.50 and bromine atom were placed at C-6 and C-7, respectively, based on the ABX 
substitution pattern of the benzene ring. Strong HMBC correlations $\left({ }^{3} J_{\mathrm{CH}}\right)$ from both $\mathrm{H}-3$ and H-6 to C-4a further supported this assignment. Thus caelestine A (1) was assigned as 7bromo-4-oxo-1,4-dihydroquinoline-2-carboxylic acid. Compound $\mathbf{1}$ has previously been synthesized and shown to be an antagonist towards the $N$-methyl-D-aspartate (NMDA) receptor. ${ }^{20}$ No spectroscopic data have been previously reported for $\mathbf{1}$.

Caelestine B (2) was isolated as a pale gum. The (+)-LRESIMS spectrum showed a cluster of pseudomolecular ions in the ratio of $1: 2: 1$ at $\mathrm{m} / \mathrm{z} 346 / 348 / 350$, indicating the presence of two bromine atoms. The molecular formula of $\mathrm{C}_{10} \mathrm{H}_{5} \mathrm{Br}_{2} \mathrm{NO}_{3}$ was determined by (-)-HRESIMS data at $\mathrm{m} / \mathrm{z} 343.8547$ [M - H]', which had one more bromine atom than $\mathbf{1}$. The ${ }^{1} \mathrm{H}$ NMR spectrum of $\mathbf{2}$ was similar to $\mathbf{1}$ except for the replacement of the ABX benzene ring system in $\mathbf{1}$ by two aromatic singlets in $\mathbf{2}$. This indicated that the additional bromine atom in 2 was also substituted on the benzene ring. 2D NMR experiments (HMBC, HSQC) were employed to assign the substituents of the benzene ring. The HMBC correlations from one of the aromatic protons at $\delta_{\mathrm{H}} 8.27$ to the carbons at $\delta_{\mathrm{C}} 176.0(\mathrm{C}-4), 139.6(\mathrm{C}-8 \mathrm{a})$, and $128.1(\mathrm{C}-7)$ placed this proton at C-5. HMBC correlations from the other aromatic proton at $\delta_{\mathrm{H}} 8.35$ to C$4\left({ }^{4} J_{\mathrm{CH}}\right.$, weak correlation), C-6, and C-4a located this proton at C-8. Thus only two positions (C-6 and C-7) were left on the benzene ring to place two bromine atoms. The para relationship of the two aromatic protons on the benzene ring was further supported by their sharp singlet signals in ${ }^{1} \mathrm{H}$ NMR spectrum, as either an ortho or meta relationship of these two protons should result in an observable ${ }^{1} \mathrm{H}-{ }^{1} \mathrm{H}$ coupling. Thus the structure of caelestine B (2) was assigned as 6,7-dibromo-4-oxo-1,4-dihydroquinoline-2-carboxylic acid.

Caelestine C (3) was isolated as a pale gum. The (+)-LRESIMS spectrum showed 1:1 ion cluster peaks at $\mathrm{m} / \mathrm{z}$ 298/300 $[\mathrm{M}+\mathrm{H}]^{+}$and 320/322 $[\mathrm{M}+\mathrm{Na}]^{+}$, indicating the presence of one bromine atom. The molecular formula of $\mathrm{C}_{11} \mathrm{H}_{8} \mathrm{BrNO}_{4}$ was determined by (+)-HRESIMS data at $m / z 297.9702[\mathrm{M}+\mathrm{H}]^{+}$. The ${ }^{1} \mathrm{H}$ NMR spectrum of 3 recorded in DMSO- $d_{6}$ (Table 1) 
showed signals for one exchangeable proton $\left[\delta_{\mathrm{H}} 11.13(\mathrm{~s})\right]$, two aromatic protons $\left[\delta_{\mathrm{H}} 7.74(\mathrm{~d}\right.$, $J=1.6 \mathrm{~Hz})$ and $7.47(\mathrm{~d}, J=1.6 \mathrm{~Hz})]$, a methoxy group $\left(\delta_{\mathrm{H}} 4.04\right)$, and a weak and broad olefinic signal at $\delta_{\mathrm{H}}$ 6.71. The aforementioned information implied 3 was an analogue of compounds 1 and 2. Unfortunately, 2D NMR correlations (HSQC and HMBC) arising from the olefinic signal at $\delta_{\mathrm{H}} 6.71$ were very weak in DMSO- $d_{6}$ and hence the structure of 3 could not be initially confirmed. This broad signal was possibly due to tautomerization between the 4-oxo-1,4-dihydroquinoline and the 4-hydroxy-quinoline moieties, which has been reported for related compounds in various solvents. ${ }^{13,19}$ In order to investigate whether a change of deuterated solvents could improve the shape of the $\mathrm{H}-3$ signal, the ${ }^{1} \mathrm{H}$ NMR spectrum of 3 was recorded in $\mathrm{CD}_{3} \mathrm{OD}$. This resulted in all the non-exchangeable protons appearing as sharp signals suggesting that $\mathbf{3}$ was present as one preferred tautomeric form in $\mathrm{CD}_{3} \mathrm{OD}$. In a similar manner to caelestines $\mathrm{A}$ and $\mathrm{B}$, the HMBC data was critical for the structure assignment of 3. In $\mathrm{CD}_{3} \mathrm{OD}$ the proton at $\delta_{\mathrm{H}} 6.97(\mathrm{H}-3)$ showed HMBC correlations to $\mathrm{C}-2$ $\left(\delta_{\mathrm{C}} 141.4\right), \mathrm{C}-4\left(\delta_{\mathrm{C}} 179.7\right), \mathrm{C}-4 \mathrm{a}\left(\delta_{\mathrm{C}} 128.0\right)$, and $-\mathrm{COOH}\left(\delta_{\mathrm{C}} 164.4\right)$ indicating that 3 shared the same ring system as compounds 1 and 2 (Figure 1). The strong ${ }^{3} J_{\mathrm{CH}} \mathrm{HMBC}$ correlation from the aromatic proton at $\delta_{\mathrm{H}} 7.92$ to $\mathrm{C}-4, \mathrm{C}-7$ and $\mathrm{C}-8 \mathrm{a}$ assigned this proton as $\mathrm{H}-5$. The meta coupling constant $\left(J=1.6 \mathrm{~Hz}\right.$, in DMSO- $\left.d_{6}\right)$ between $\mathrm{H}-5$ and the other aromatic proton at $\delta_{\mathrm{H}} 7.47$ required the latter to be placed at C-7. The methoxy group was located at C-8, as the only ROESY correlation observed in $\mathbf{3}$ was between $\mathrm{H}-7$ and 8-OMe. The existence of the 8-OMe was further supported by the upfield-shifted carbon signals of C-5 ( $\left.\Delta \delta_{\mathrm{C}}>7 \mathrm{ppm}\right)$ and C-8a $\left(\Delta \delta_{\mathrm{C}}>8 \mathrm{ppm}\right)$ compared with those in compounds $\mathbf{1}$ and $\mathbf{2}$, as the insertion of methoxy group has shielding effects at the ortho and para positions of a benzene system. ${ }^{21}$ Subsequently, a bromine atom was placed at C-6. Hence the structure of caelestine C (3) was assigned as 6-bromo-8-methoxy-4-oxo-1,4-dihydroquinoline-2-carboxylic acid. 
Caelestine D (4) was assigned a molecular formula of $\mathrm{C}_{11} \mathrm{H}_{7} \mathrm{Br}_{2} \mathrm{NO}_{4}$ on the basis of ()-HRESIMS data, which had one more bromine atom than 3. The ${ }^{1} \mathrm{H}$ NMR spectrum of 4 recorded in DMSO- $d_{6}$ only exhibited three singlets, which were assigned to an exchangeable proton $\left(\delta_{\mathrm{H}} 11.13\right)$, an aromatic proton $\left(\delta_{\mathrm{H}} 8.15\right)$, and a methoxy group ( $\left.\delta_{\mathrm{H}} 4.04\right)$. The absence of the olefinic signal (H-3) in DMSO- $d_{6}$ implied that 4 also underwent tautomerization. We postulated that $\mathbf{4}$ might be present as one preferred tautomeric form in a polar protic solvent as shown for 3 in $\mathrm{CD}_{3} \mathrm{OD}$. Unfortunately, 4 was only partially soluble in $\mathrm{CD}_{3} \mathrm{OD}$, which prevented good quality 2D NMR data from being obtained. Hence one drop of $\mathrm{H}_{2} \mathrm{O}$ was added to the DMSO- $d_{6}$ solution, which resulted in the appearance of the H-3 signal at $\delta_{\mathrm{H}} 6.65$ in the ${ }^{1} \mathrm{H}-\mathrm{NMR}$ spectrum. The aforementioned information implied that $\mathbf{4}$ was an analogue of 3, with the only structural difference occurring on the benzene ring. Analysis of 2D NMR data recorded in wet DMSO- $d_{6}$ allowed the structure of 4 to be determined. The aromatic proton at $\delta_{\mathrm{H}} 8.11$ was assigned as $\mathrm{H}-5$ on the basis of a strong HMBC correlation from this proton to a conjugated ketone at $\delta_{\mathrm{C}} 176.4(\mathrm{C}-4)$. As no ROESY correlations were observed between $\mathrm{H}-5$ and methoxy group, and $\mathrm{H}-5$ had a strong HMBC correlation with the carbon at $\delta_{\mathrm{C}} 118.9(\mathrm{C}-7)$ while a weak correlation with the carbon at $\delta_{\mathrm{C}} 148.8(\mathrm{C}-8)$, the methoxy group was placed at C-8. This assignment was further confirmed by comparison of the carbon chemical shifts of $\mathbf{4}$ with 2 . The chemical shifts of C-5, C-7, and C-8a in $\mathbf{4}$ were shifted upfield by 4.9, 9.2, and $5.8 \mathrm{ppm}$, respectively, compared to those in 2 , since the presence of methoxy group at C-8 had shielding effects at the ortho and para positions. ${ }^{21}$ Subsequently, two bromine atoms were placed at C-6 and C-7. Thus the structure of caelestine D (4) was assigned as 6,7-dibromo-8-methoxy-4-oxo-1,4-dihydroquinoline-2-carboxylic acid.

Table 3 shows the in vitro activity of compounds 1-4 against three mammalian cell types. MCF-7 is derived from a breast adenocarcinoma cancer, MM96L is an amelanotic 
metastatic melanoma cell line, and NFF (neonatal foreskin fibroblasts) is a "normal” primary cell type. The NFF cells are routinely used in toxicity studies to determine compound selectivity for cancer cells. All compounds (1-4) showed only minor activity at $100 \mu \mathrm{M}$. Compounds 1-4 were also tested against a panel of ATCC and NCTC type stains of microbes known to be associated with nosocomial infections that included multi-drug resistant Staphylococcus aureus (ATCC 43300), methicillin sensitive Staphylococcus aureus (ATCC 25923), Escherichia coli (ATCC 25922), Enterococcus faecalis (ATCC 19433), Pseudomonas aeruginosa (NCTC 10662) and Candida albicans (ATCC 10231). At concentrations ranging from $0.1 \mu \mathrm{M}$ to $10 \mathrm{mM}$ no microbial growth inhibition was observed after $20 \mathrm{~h}$ of incubation.

\section{Experimental Section}

General Experimental Procedures. UV and IR spectra were recorded on a Jasco V-650 UV/Vis spectrophotometer and a Bruker Tensor 27 spectrometer, respectively. NMR spectra were recorded at $30{ }^{\circ} \mathrm{C}$ on either a Varian $500 \mathrm{MHz}$ or a $600 \mathrm{MHz}$ Unity INOVA spectrometer. The latter spectrometer was equipped with a triple resonance cold probe. The ${ }^{1} \mathrm{H}$ and ${ }^{13} \mathrm{C}$ NMR chemical shifts were referenced to the solvent peak for DMSO- $d_{6}$ at $\delta_{\mathrm{H}} 2.49$ and $\delta_{\mathrm{C}} 39.5$, and for $\mathrm{CD}_{3} \mathrm{OD}$ at $\delta_{\mathrm{H}} 3.31$ and $\delta_{\mathrm{C}}$ 49.0. LRESIMS spectra were recorded on a Waters ZQ mass spectrometer. HRESIMS data were recorded on a Bruker Daltronics Apex III 4.7e Fourier-transform mass spectrometer. A BIOLINE orbital shaker was used for the large-scale extraction of ascidian material. Alltech Davisil 40-60 $\mu \mathrm{m} 60 \AA \mathrm{C}_{18}$ bonded silica was used for pre-adsorption work. A Waters 600 pump equipped with a Waters 996 PDA detector and a Waters 717 autosampler were used for HPLC. A Phenomenex Luna $5 \mu \mathrm{C}_{18}$ column $(21.2 \times 250 \mathrm{~mm})$ were used for semi-preparative HPLC separation. All solvents used 
for chromatography, UV, and MS were Lab-Scan HPLC grade, and the $\mathrm{H}_{2} \mathrm{O}$ was Millipore Milli-Q PF filtered.

Animal Material. The ascidian Aplidium caelestis (Monniot 1987) was collected by SCUBA diving at a depth of 12.9 m from Manta Ray Bommie, North Stradbroke Island, Queensland, Australia, in February, 2005. A voucher sample, QMG322279, was lodged at the Queensland Museum, South Brisbane, Queensland, Australia.

Extraction and Isolation. The freeze-dried and ground ascidian (20 g) was transferred to a conical flask ( $1 \mathrm{~L})$ and $n$-hexane $(250 \mathrm{~mL})$ was added and the flask shaken at $200 \mathrm{rpm}$ for $2 \mathrm{~h}$. The $n$-hexane extract was filtered under gravity, then discarded. $\mathrm{CHCl}_{3}: \mathrm{MeOH}$ mixture $(4: 1$, $250 \mathrm{~mL}$ ) was added to the de-fatted marine material in the conical flask and shaken at 200 rpm for $2 \mathrm{~h}$. The resulting extract was filtered under gravity, and set aside. $\mathrm{MeOH}(250 \mathrm{~mL})$ was added and the $\mathrm{MeOH} /$ ascidian mixture was shaken for a further $2 \mathrm{~h}$ at $200 \mathrm{rpm}$. Following gravity filtration the marine material was extracted with another volume of $\mathrm{MeOH}$ (250 mL), while being shaken at $200 \mathrm{rpm}$ for $16 \mathrm{~h}$. All $\mathrm{CHCl}_{3} / \mathrm{MeOH}$ extracts were combined and dried under reduced pressure to yield a dark brown solid (1.2 g). This solid was redissolved into a $\mathrm{CHCl}_{3}: \mathrm{MeOH}$ mixture $(4: 1,50 \mathrm{~mL})$, then filtered under gravity to remove the salt. The resulting solution was dried down to give a desalted residue $(0.45 \mathrm{~g})$. This residue was pre-adsorbed on $\mathrm{C}_{18}$-bonded silica, then packed into a stainless steel cartridge (10 $\times 30 \mathrm{~mm}$ ) that was subsequently attached to a $\mathrm{C}_{18}$ Luna HPLC column. Isocratic HPLC conditions of $90 \% \mathrm{H}_{2} \mathrm{O}(0.1 \%$ TFA) $/ 10 \% \mathrm{MeOH}(0.1 \%$ TFA) were initially employed for the first $10 \mathrm{~min}$, then a linear gradient to $\mathrm{MeOH}(0.1 \%$ TFA) was run over $40 \mathrm{~min}$, followed by isocratic conditions of $\mathrm{MeOH}(0.1 \%$ TFA) for a further $10 \mathrm{~min}$, all at a flow rate of $9 \mathrm{~mL} / \mathrm{min}$. Sixty fractions $(60 \times 1 \mathrm{~min})$ were collected from time $=0 \mathrm{~min}$. Following lyophilization 
fractions 29, 31, 33, and 35 yielded pure 1 (1.5 mg, 0.0075\% dry wt), 3 (2.1 mg, 0.0105\% dry wt), 2 (1.1 mg, 0.0055\% dry wt), and 4 (2.3 mg, 0.0115\% dry wt), respectively.

Caelestine A (1): pale gum; UV (MeOH) $\lambda_{\max }(\log \varepsilon) 356$ (3.21), 340 (3.32), 251 (3.63), 223 (3.87) nm; IR $v_{\max }(\mathrm{KBr}) 1696$ (br), 1623, 1589, 1561, 1509, 1456, 1402, 1295 (br), 1243, 1205, 1141, 1065, $826 \mathrm{~cm}^{-1} ;{ }^{1} \mathrm{H}(600 \mathrm{MHz})$ and ${ }^{13} \mathrm{C}(125 \mathrm{MHz}) \mathrm{NMR}$, see Table 1 and 2, respectively; (+)-LRESIMS m/z (35 eV) (rel. int.) $268\left[\mathrm{C}_{10} \mathrm{H}_{6}{ }^{79} \mathrm{BrNO}_{3}+\mathrm{H}\right]^{+}$(92), 270 $\left[\mathrm{C}_{10} \mathrm{H}_{6}{ }^{81} \mathrm{BrNO}_{3}+\mathrm{H}\right]^{+}$(100); (+)-HRESIMS m/z 267.9597 (calcd for $\mathrm{C}_{10} \mathrm{H}_{7}{ }^{79} \mathrm{BrNO}_{3}$, 267.9604).

Caelestine B (2): pale gum; UV (MeOH) $\lambda_{\max }(\log \varepsilon) 350$ (3.53), 263 (4.00), 224 (4.12) nm; IR $v_{\max }(\mathrm{KBr}) 1721$ (br), 1628, 1587, 1494, 1439, 1403, 1205, 1137, $801 \mathrm{~cm}^{-1}$; ${ }^{1} \mathrm{H}$ (600 MHz) and ${ }^{13} \mathrm{C}(125 \mathrm{MHz}) \mathrm{NMR}$, see Table 1 and 2, respectively; (+)-LRESIMS m/z (35 eV) (rel. int.) $346\left[\mathrm{C}_{10} \mathrm{H}_{5}{ }^{79} \mathrm{Br}_{2} \mathrm{NO}_{3}+\mathrm{H}\right]^{+}$(42), $348\left[\mathrm{C}_{10} \mathrm{H}_{5}{ }^{79} \mathrm{Br}^{81} \mathrm{BrNO}_{3}+\mathrm{H}\right]^{+}$(100), 350 $\left[\mathrm{C}_{10} \mathrm{H}_{5}{ }^{81} \mathrm{Br}_{2} \mathrm{NO}_{3}+\mathrm{H}\right]^{+}$(42); (-)-HRESIMS $\mathrm{m} / \mathrm{z} 343.8547$ (calcd for $\mathrm{C}_{10} \mathrm{H}_{4}{ }^{79} \mathrm{Br}_{2} \mathrm{NO}_{3}$, 343.8563).

Caelestine C (3): pale gum; UV (MeOH) $\lambda_{\max }(\log \varepsilon) 347$ (3.25), 244 (3.80), 227 (3.77) nm; IR $v_{\max }(\mathrm{KBr}) 1679$ (br), 1514, 1439, 1203, 1138, 1064, $801 \mathrm{~cm}^{-1}$; ${ }^{1} \mathrm{H}(600 \mathrm{MHz})$ and ${ }^{13} \mathrm{C}(125 \mathrm{MHz})$ NMR, see Table 1 and 2, respectively; (+)-LRESIMS m/z (35 eV) (rel. int.) $298\left[\mathrm{C}_{11} \mathrm{H}_{8}{ }^{79} \mathrm{BrNO}_{4}+\mathrm{H}\right]^{+}$(95), $300\left[\mathrm{C}_{11} \mathrm{H}_{8}{ }^{81} \mathrm{BrNO}_{4}+\mathrm{H}\right]^{+}$(100), $320\left[\mathrm{C}_{11} \mathrm{H}_{8}{ }^{79} \mathrm{BrNO}_{4}+\right.$ $\mathrm{Na}]^{+}$(35), $322\left[\mathrm{C}_{11} \mathrm{H}_{8}{ }^{81} \mathrm{BrNO}_{4}+\mathrm{Na}\right]^{+}$(38); (+)-HRESIMS m/z 297.9702 (calcd for $\left.\mathrm{C}_{11} \mathrm{H}_{9}{ }^{79} \mathrm{BrNO}_{4}, 297.9709\right)$.

Caelestine D (4): pale gum; UV (MeOH) $\lambda_{\max }(\log \varepsilon) 355$ (3.48), 340 (3.47), 255 (3.93), 225 (4.01) nm; IR $v_{\max }(\mathrm{KBr})$ 1623, 1582, 1549, 1503, 1452, 1417, 1392, 1196, 1039, 932, $805 \mathrm{~cm}^{-1}$; ${ }^{1} \mathrm{H}(600 \mathrm{MHz})$ and ${ }^{13} \mathrm{C}(150 \mathrm{MHz})$ NMR, see Table 1 and 2, respectively; (+)LRESIMS m/z (35 eV) (rel. int.) $376\left[\mathrm{C}_{11} \mathrm{H}_{7}{ }^{79} \mathrm{Br}_{2} \mathrm{NO}_{4}+\mathrm{H}\right]^{+}$(45), $378\left[\mathrm{C}_{11} \mathrm{H}_{7}{ }^{79} \mathrm{Br}^{81} \mathrm{BrNO}_{4}+\right.$ 
$\mathrm{H}]^{+} \quad$ (100); $380\left[\mathrm{C}_{11} \mathrm{H}_{7}{ }^{81} \mathrm{Br}_{2} \mathrm{NO}_{4}+\mathrm{H}\right]^{+}$(48); (-)-HRESIMS m/z 373.8662 (calcd for $\left.\mathrm{C}_{11} \mathrm{H}_{6}{ }^{79} \mathrm{Br}_{2} \mathrm{NO}_{4}, 373.8669\right)$.

Mammalian cell assays. The experimental details of the mammalian cell assays have been described in a previous publication. ${ }^{22}$ Doxorubicin was used as a positive control for all assays and gave 99\% inhibition of MCF-7 and MM96L, and 95\% inhibition of NFF at $1 \mu \mathrm{M}$.

Antimicrobial Assays. Antimicrobial activities were evaluated using the CLSI broth microdilution assay ${ }^{23}$ with each compound screened in a decimal dilution series commencing from $0.1 \mu \mathrm{M}$ to $10 \mathrm{mM}$.

Acknowledgment. We thank H. T. Vu from Griffith University for acquiring the HRESIMS measurements. We would also like to thank J. N. A. Hooper from the Queensland Museum for ascidian collection and identification. M. Boddington and R. Graham from the University of Southern Queensland are acknowledged for technical assistance with the antimicrobial assays.

Supporting Information Available: NMR data for caelestines A-D (1-4). This material is available free of charge via the Internet at http://pubs.acs.org.

\section{References and Notes}

(1) Bolognese, A.; Liberatore, R.; Riente, G.; Scherillo, G. J. Heterocycl. Chem. 1988, 25, 1247-1250.

(2) Schildknecht, H. Z. Naturforsch., B, 1969, 24, 38-47. 
(3) Wang, S. F.; Braekman, J. C.; Daloze, D.; Pasteels, J.; Soetens, P.; Handjieva, N. V.; Kalushkov, P. Experientia 1996, 52, 628-630.

(4) Gonzalez, A.; Schroeder, F.; Meinwald, J.; Eisner, T. J. Nat. Prod. 1999, 62, 378-380.

(5) Neuenhaus, W.; Budzikiewicz, H.; Korth, H.; Pulverer, G. Z. Naturforsch. B: Chem. Sci. 1980, 35, 1569-1571.

(6) Breidingmack, S.; Zeeck, A. J. Antibiot. 1987, 40, 953-960.

(7) Nagata, H.; Ochiai, K.; Aotani, Y.; Ando, K.; Yoshida, M.; Takahashi, I.; Tamaoki, T. J. Antibiot. 1997, 50, 537-542.

(8) Starratt, A. N.; Caveney, S. Phytochemistry 1996, 42, 1477-1478.

(9) Mitaku, S.; Skaltsounis, A. L.; Tillequin, F.; Koch, M.; Pusset, J.; Sevenet, T. Nat. Prod. Res. 1995, 7, 219-225.

(10) Al-Khalil, S.; Alkofahi, A.; El-Eisawi, D.; Al-Shibib, A. J. Nat. Prod. 1998, 61, 262263.

(11) Lepkoovsky, S. R., E.; Haagen-Smit, A. J. J. Biol. Chem. 1943, 149, 195-201.

(12) Lewis, R. J., Sr. In Sax's Dangerous Properties of Industrial Materials; John Wiley and Sons: New York, 2000; 10th ed; Vol. 1-3.

(13) Molinski, T. F.; Faulkner, D. J. Tetrahedron Lett. 1988, 29, 2137-2138.

(14) Desilva, E. D.; Miao, S. C.; Andersen, R. J.; Schultz, L. W.; Clardy, J. Tetrahedron Lett. 1992, 33, 2917-2920.

(15) Pearce, A. N.; Appleton, D. R.; Babcock, R. C.; Copp, B. R. Tetrahedron Lett. 2003, 44, 3897-3899.

(16) McKay, M. J.; Carroll, A. R.; Quinn, R. J. J. Nat. Prod. 2005, 68, 1776-1778.

(17) Davis, R. A.; Carroll, A. R.; Quinn, R. J. J. Nat. Prod. 2002, 65, 454-457.

(18) Davis, R. A.; Carroll, A. R.; Quinn, R. J. J. Nat. Prod. 1999, 62, 1405-1409.

(19) Yin, S.; Cullinane, C.; Carroll, A. R.; Quinn, R. J.; Davis, R. A. Tetrahedron Lett. 2010, 51, 3403-3405.

(20) Leeson, P. D.; Baker, R.; Carling, R. W.; Curtis, N. R.; Moore, K. W.; Williams, B. J.; Foster, A. C.; Donald, A. E.; Kemp, J. A.; Marshall, G. R. J. Med. Chem. 1991, 34, 12431252.

(21) Pretsch, E.; Bühlmann, P.; Affolter, C. In Structure Determination of Organic Compounds; Springer-Verlag Berlin Heidelberg New York, 2000; p97.

(22) Davis, R. A.; Carroll, A. R.; Andrews, K. T.; Boyle, G. M.; Tran, T. L.; Healy, P. C.; Kalaitzis, J. A.; Shivas, R. G. Org. Biomol. Chem., 2010, 8, 1785-1790. 
(23) Wikler, M. A.; Low, D. E.; Cockerill, F. R.; Sheehan, D. J.; Craig, W. A.; Tenover, F. C.; Dudley, M. N. In Methods for Dilution Antimicrobial Susceptibility tests for bacteria that grow aerobically; Approved standard-seventh edition. CLSI (formerly NCCLS), 2006; Vol. 26, pp. M7-A7. 
Table 1. ${ }^{1} \mathrm{H}$ NMR (600 MHz) Data for Caelestines A-D (1-4).

\begin{tabular}{|c|c|c|c|c|c|c|c|}
\hline \multirow[t]{2}{*}{ No } & 1 & 2 & \multicolumn{2}{|l|}{3} & \multicolumn{3}{|c|}{4} \\
\hline & $\delta_{\mathrm{H}}{ }^{a}$ & $\delta_{\mathrm{H}}{ }^{a}$ & $\delta_{\mathrm{H}}{ }^{a}$ & $\delta_{\mathrm{H}}^{b}$ & $\delta_{\mathrm{H}}{ }^{a}$ & $\delta_{\mathrm{H}}^{b}$ & $\delta_{\mathrm{H}}{ }^{c}$ \\
\hline 3 & $6.63, \mathrm{~s}$ & $6.66, \mathrm{~s}$ & 6.71, brs & $6.97, \mathrm{~s}$ & N.O. & $6.95, \mathrm{~s}$ & $6.65, \mathrm{~s}$ \\
\hline 5 & $7.98, \mathrm{~d}(8.6)$ & $8.27, \mathrm{~s}$ & 7.74, d (1.6) & 7.92, s & $8.15, \mathrm{~s}$ & $8.30, \mathrm{~s}$ & $8.11, \mathrm{~s}$ \\
\hline 6 & 7.50, dd $(8.6,1.8)$ & & & & & & \\
\hline 7 & & & 7.47, d (1.6) & $7.44, \mathrm{~s}$ & & & \\
\hline 8 & 8.17, d (1.8) & $8.35, \mathrm{~s}$ & & & & & \\
\hline 8-OMe & & & $4.04, \mathrm{~s}$ & $4.10, \mathrm{~s}$ & $4.04, \mathrm{~s}$ & $4.08, \mathrm{~s}$ & 3.98, s \\
\hline $\mathrm{NH}$ & $11.14, \mathrm{~s}$ & 11.14, s & 11.13, s & & 11.13, s & & \\
\hline $\mathrm{COOH}$ & 11.98 , brs & 12.10 , brs & N.O. & & N.O. & & \\
\hline
\end{tabular}

${ }^{a}$ in $\mathrm{DMSO}^{-} d_{6}{ }^{b}$ in $\mathrm{CD}_{3} \mathrm{OD}^{c}$ in DMSO- $d_{6} / \mathrm{H}_{2} \mathrm{O}(17: 1)$. N.O. = not observed

Table 2. ${ }^{13} \mathrm{C}$ NMR (125 MHz) Data for Caelestines A-D (1-4).

\begin{tabular}{|c|c|c|c|c|}
\hline No & $\mathbf{1}^{a}$ & $2^{a}$ & $3^{b}$ & $4^{C}$ \\
\hline 2 & 139.5, C & 140.0, C & $141.4,^{d} \mathrm{C}$ & $145.8,{ }^{d} \mathrm{C}$ \\
\hline 3 & 110.5, CH & 110.5, CH & 111.4, CH & 108.6, CH \\
\hline 4 & 177.2, C & 176.0, C & $179.7,{ }^{d} \mathrm{C}$ & $176.4,{ }^{d} \mathrm{C}$ \\
\hline $4 a$ & 124.5, C & 125.9, C & 128.0, C & 125.9, C \\
\hline 5 & 127.0, CH & 129.3, CH & 119.9, CH & 124.4, CH \\
\hline 6 & 127.0, CH & 118.9, C & 119.3, C & 121.9, C \\
\hline 7 & 126.0, C & 128.1, C & 116.5, CH & 118.9, C \\
\hline 8 & 121.8, CH & 124.6, CH & 151.3, C & $148.8,{ }^{d} \mathrm{C}$ \\
\hline $8 a$ & 141.1, C & 139.6, C & 131.1, C & $133.8,{ }^{d} \mathrm{C}$ \\
\hline$-\mathrm{COOH}$ & 163.4, C & 163.2, C & 164.4, C & $162.8,{ }^{d} \mathrm{C}$ \\
\hline 8-OMe & & & $57.7, \mathrm{CH}_{3}$ & 61.7, $\mathrm{CH}_{3}$ \\
\hline
\end{tabular}

Table 3. In vitro Cytotoxicity of Caelestines A-D (1-4)

\begin{tabular}{|c|c|c|c|}
\hline \multirow{2}{*}{ Compound } & \multicolumn{3}{|c|}{ Mammalian Cells $[\%$ inhibition at $100 \mu \mathrm{M}( \pm \mathrm{SD})]$} \\
\hline & MCF-7 & MM96L & NFF \\
\hline 1 & $39( \pm 3)$ & $62( \pm 11)$ & $57( \pm 5)$ \\
\hline 2 & $49( \pm 8)$ & $69( \pm 6)$ & $66( \pm 2)$ \\
\hline 3 & $40( \pm 5)$ & $54( \pm 3)$ & $58( \pm 2)$ \\
\hline 4 & $38( \pm 5)$ & $52( \pm 6)$ & $68( \pm 13)$ \\
\hline
\end{tabular}




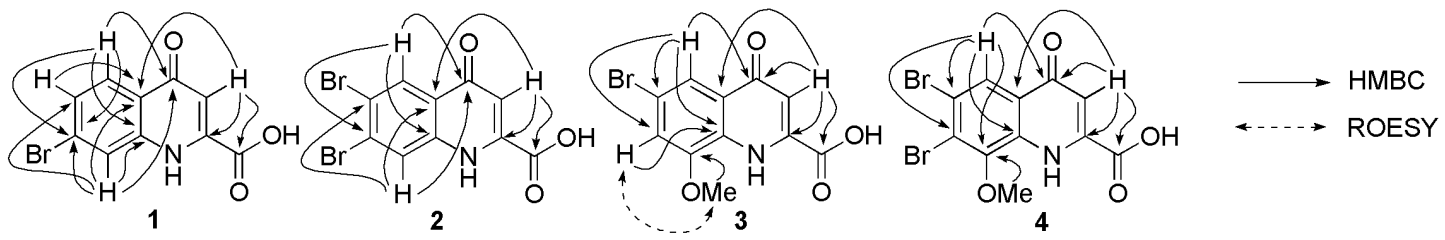

Figure 1. Selected HMBC and ROESY Correlations for Caelestines A-D (1-4). 
Table of Contents Graphic
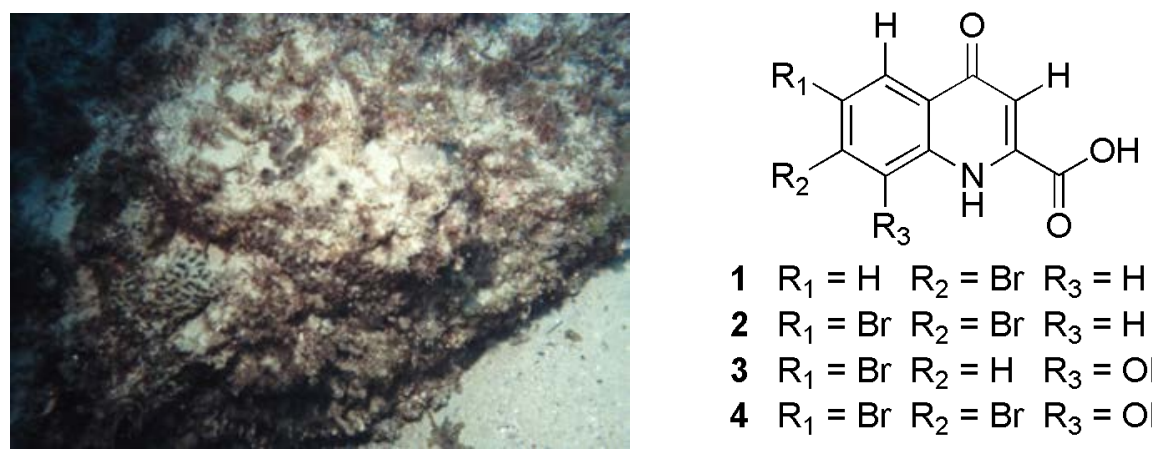

$1 \quad R_{1}=H \quad R_{2}=B r \quad R_{3}=H$

$2 \mathrm{R}_{1}=\mathrm{Br} \mathrm{R}_{2}=\mathrm{Br} \mathrm{R}_{3}=\mathrm{H}$

$3 \quad \mathrm{R}_{1}=\mathrm{Br} \quad \mathrm{R}_{2}=\mathrm{H} \quad \mathrm{R}_{3}=\mathrm{OMe}$

$4 \mathrm{R}_{1}=\mathrm{Br} \mathrm{R}_{2}=\mathrm{Br} \mathrm{R}_{3}=\mathrm{OMe}$ 